\title{
Molecular study of Anaplasma marginale parasite in carrier cattle in Al-Nasiriyah city
}

\author{
N.R. Al- Kasar*, M.M. Flayyih and A.D. Al-Jorany \\ College of Veterinary Medicine, University of Thi qar, Thi qar, Iraq, *E.mail: nuthaila-n@utq.edu.iq
}

(Received February 17, 2018; Accepted September 3, 2018)

\begin{abstract}
To detect Anaplasma marginale among carrier cattle by using polymerase chain reaction (PCR) technique, 64 blood samples, from healthy cows in abattoir of Al-Nasiriyah city were collected from June till August, 2017 in this study. By targeting MAR1bB2 gene with the molecular weight of approximately $265 \mathrm{bp}$, Anaplasma marginale were detected in 18 samples (28.125\%). One of these positive sample was recoded in National Center for Biotechnology Information, NCBI; Gene Bank.
\end{abstract}

Keywords: Anaplasmosis, Anaplasma marginale, Protozoa, PCR

Available online at http://www.vetmedmosul.com

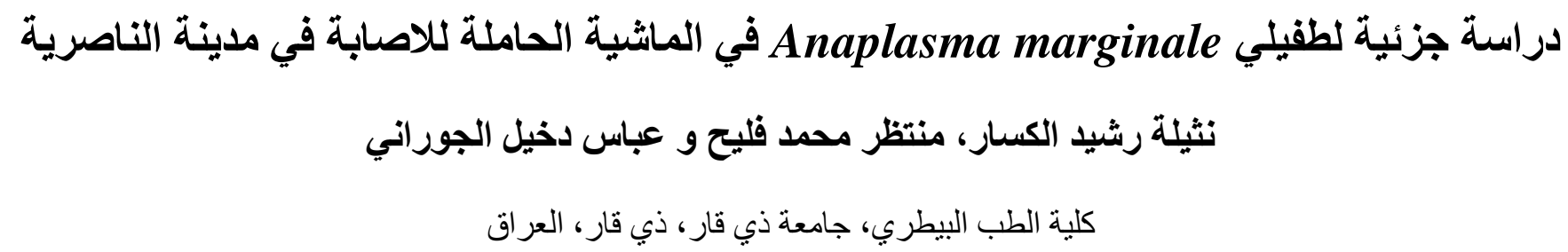

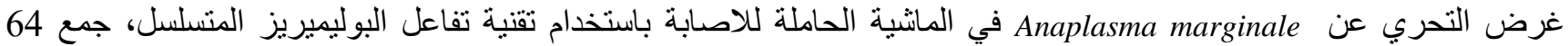

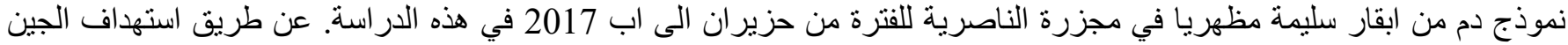

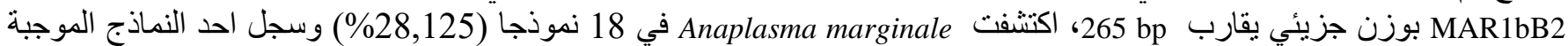
في المركز الوطني لمعلومات التقانات الحيوية، بنك الجينات.

\section{Introduction}

Anaplasma marginale, the tick-borne obligate intraerythrocytic pathogens cause bovine anaplasmosis in cattle and wild ruminants (1). In addition to biological transmission by ixodid ticks, Mecanichal transmission of bovine anaplasmosis may also be occurred by biting of flies or blood contaminated tools (2). The study of (3) reported that Anaplasma marginale can be transmitted transplacentalLy. A high economic losses due to bovine anaplasmosis were reported in the tropical and subtropical area, as well as, this disease cause a huge problems for management and health of livestock in these regions (4). Cattle which were recovered clinically from this disease may become carrier lifelong and serve as reservoir (5). In pre symptomatic and carrier animals,traditional diagnosis which based on microscopic examination of Giemsa stained blood smear may be useless (6), so this study aimed to investigate bovine anaplasmosis in carrier cattle in AlNasiriyah city by using polymerase chain reaction (PCR) technique.

\section{Material and methods}

\section{Samples}

To collect blood samples, 64 healthy cows from abattoir of Al-Nasiriyah city southern Iraq which were randomly selected from June till August, 2017. Blood samples were taken from jugular veins of these cows. By using ice-pack containers these blood samples were brought 
to PCR unit in college of veterinary medicine, university of Thiqar.

\section{Extraction of DNA}

A volume of $200 \mu \mathrm{l}$ fresh blood was extracted by DNA extraction kit (geneaid) as recommended by Manufacturer.

\section{PCR assay}

PCR assay targeting MAR1bB2 gene an element of A.marginale (7) was used for detecting A.marginale. The primers (Forward: 5-GCT CTA GCA GGT TAT GCG TC3/Reverse 50-CTG CTT GGG AGAATG CAC CT-3) were used to amplify a $265 \mathrm{bp}$.

The PCR mixture $(50 \mu \mathrm{l})$ : DNA templates $10 \mu \mathrm{l}$, Mastermix $10 \mu \mathrm{l}$, Primer forward $2 \mu \mathrm{l}$, Primer reverse $2 \mu \mathrm{l}$, DW $26 \mu 1$.

The PCR conditions for A.marginale included 1 cycle of an initial denaturation of DNA at $94^{\circ} \mathrm{c}$ for for $3 \mathrm{~min}$. followed by 30 cycles of denaturation ( $95 \mathrm{c}$ for $50 \mathrm{~s}$ ), primer annealing (50c for $50 \mathrm{~s}$ ) and extension at $65^{\circ} \mathrm{c}$ for $1 \mathrm{~min}$. A final extension at $65^{\circ} \mathrm{c}$ for $10 \mathrm{~min}$ was performed. For each reaction, $10 \mu 1$ of PCR product was electrophoresed on $2 \%$ agarose gel containing $1 \mu \mathrm{l} / \mathrm{ml}$ ethidium bromide at 70 Voltage and visualized under U.V. light.

\section{DNA sequencing}

Only two PCR products of MAR1bB2gene in A.marginale isolates were chosen for sequencing, and forward primer for this gene, and sent outside Iraq to be sequenced (Macrogen, Korea). Basic Local Alignment Search Tool analysis (BLAST) was lead to blast algorithm. The samples sequences were edited, aligned, and compared with the reference sequences using sequence alignment (8).

\section{Results and discussion}

The previous studies indicate that msplb of $A$. marginale genome is a very sensitive and specific target for detection of A. marginale infection in ticks and in cattle hosts $(6,9)$. The primer set successfully amplified all available stocks and the sequence of PCR amplified fragments also sensitivity and specificity of this primer was shown to be identical at the nucleotide sequences. These results suggest that the MAR1bB2 primers may be suitable to detect A. marginale isolates from world. In this study, out of 64 collected blood sample, only18 $(28.125 \%)$ was identified as Anaplasma marginale which amplified the targeted gene, with the molecular weight of approximately 265 bp (Fig. 1).

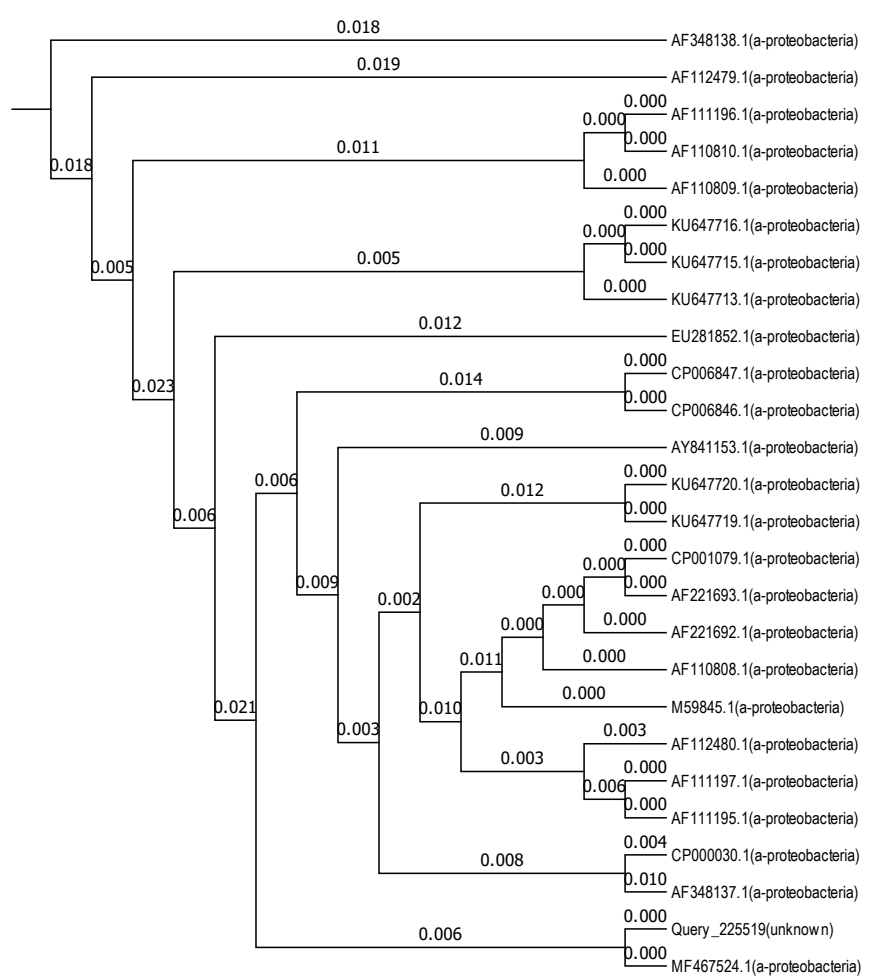

Figure 1: Evolutionary relationships of taxa, based on MARIbB2gene gene partial sequence that used for Anaplasma marginaledetection from animals samples. 
One of these possitive samples was recoded in National Center for Biotechnology Information, NCBI; Gene Bank, under name (Anaplasma marginale strain abbas4 major surface protein $1 \mathrm{~b}$ MAR1bB2 gene, partial cds). under accession number MF467524. Evolutionary analyses were conducted in MEGA7 (4). A. marginale infection was reported by many studies done in different parts of Iraq. The result of current study is higher than infection rate reported by (10) who recorded $9.09 \%$ of cattle in Erbil and (11) who reported in $13.04 \%$ of cattle in Wassit by using ELISA test. The infection rate of this study is lower than $73 \%$ of cattle by competitive ELISA which published by (12) in Al-Nasiriyah city, $30.4 \%$ of cattle which recorded by (13) in Al-Diwanyia and 35\% of cattle in Wassit which recorded by (14) by using ELISA test. These differences of the results may be due to alternative diagnostic techniques and different environmental conditions of these different area.

\section{References}

1. Rajput Z, Hu S, Arijo A, Habi M, Khalid M. Comparative study of Anaplasma parasites in tick carrying buffaloes and cattle. J Zhej Uni Sci. 2005;6(11):1057-1062.

2. Kocan K, Blouin E, Barbet A. Anaplasmosis control. past, present, and future. Ann NY Acad Sci. 2000;916:501-509.

3. Aktas M, Özübek S. Outbreak of anaplasmosis associated with novel genetic variants of Anaplasma marginale in a dairy cattle. Compar Immun Microb Infec Dis J. 2017;54:20-26.
4. Kumar S, Stecher G, Tamura K. MEGA7: Molecular evolutionary genetics analysis version 7.0 for bigger data sets. Molec Bio Evol. 2016;33:1870-1874.

5. Aubry P, Geale D. A Review of bovine anaplasmosis. Trans Emerg Dis. 2011;58:1-30.

6. Carelli G, Decaro N, Lorusso A, Elia G, Lorusso E, Mari V, Ceci L, Buonavoglia C. Detection and quantification of Anaplasma marginale DNA in blood samples of cattle by real-time PCR. Vet Microbiol. 2007;124:107-114.

7. Bilgic H, Tulin K, Martin S, Brian S, Andy T, Hasan E, William W. Development of a multiplex PCR assay for simultaneous detectionof Theileria annulata, Babesia bovis and Anaplasma marginale in cattle. Exper Parasitol. 2012;133:222-229.

8. Hall TA. Bio edit: a user-friendly biological sequence alignment editor and analysis program for windows 95/98 NT. Nucl Acids Symb Ser. 1999;41:95-98.

9. Molad T, Mazuz M, Fleiderovitz L, Fish L, Savitsky I, Krigel Y, Leibovitz B, Molloy J, Jongejan F, Shkap V. Molecular and serological detection of A.centrale and A. marginale infected cattle grazing within an endemic area. Vet Microbiol. 2006;113:55-62.

10. Ameen K, Abdullah B, Abdul-Razaq R. Seroprevalence of Babesia bigemina and Anaplasma marginale in domestic animals in Erbil, Iraq. Iraq J Vet Sci. 2012;26:109-114.

11. Agaar O, Jassem G. Some molecular and sero - prevalence study of Anaplasma marginale in cattle in Wassit province. AL-Qadisiya J Vet Med Sci. 2005;14(1):27-33.

12. Gati J. Seroprevalence of Anaplasma marginale among cows in Nasiriya city- South of Iraq- by competitive ELISA. Al Qadisiya J Vet Med Sci. 2012;11(1):105-108

13. Al-Mossawy H. A Serological investigation of bovine anaplasmosis in Al- Diwanyia city (Diploma thesis). AL-Qadisiya: AL-Qadisiya University; 2012;pp:111.

14. Al-gharban H, Dhahir S. Serological diagnosis of persistent infection with Anaplasma marginale bacteria in cattle. Iraqi $\mathrm{J}$ Vet Med. 2015;39(1):33-39. 